\title{
Immigration policy and research in Canada: pure or applied?
}

\author{
Anthony H. Richmond
}

Abstract A review of Canadian immigration research, published between 1980 and 1998, suggests that research had only a limited impact on policies and programmes. Economists seemed to have more influence than psychologists, sociologists or demographers. Alternative models of the way research may enter the policy decision-making process are described. A 'systems' model recognises the competing influence of special interest groups and the influence of public opinion. Emphasis is placed on the need for academic researchers to make their conclusions known expeditiously, in order to create a more enlightened public.

KEYWORDS: IMMIGRATION; APPLIED RESEARCH; CANADA

A key question in policy studies concerns the utilisation of research in policymaking. Dobuzinskis (1996: 118-9) noted that there has been a 'burgeoning literature' on the utilisation of social science research in policy-making, but 'not much has been written on the Canadian case'. However, Brooks and Gagnon $(1988,1990)$ traced the changes that have occurred since World War II, comparing the experience of Quebec with that of English Canada, concerning social scientists, policy and the state. They noted the growing importance of the 'expert'. Economists, particularly, are what they call a 'clerisy linked to the dominant segment of the capitalist class' (Brooks and Gagnon 1988: 104). Lawyers with special qualifications in the fields of corporate and international law play a similar role. The activities of the expert may be contrasted with that of the disinterested researcher, on the one hand, and the 'social critic' on the other. The latter may question the fundamental beliefs and values determining policy decisions, whereas the policy critic shares the dominant values and goals pursued, questioning only the means proposed for their implementation.

The social sciences can never be entirely 'value-free' or neutral, but, as Myrdal's (1958) classic discussion of values in social theory indicated, it is important for those undertaking research, whether it is understood as 'pure' or 'applied', to make their assumptions and value-judgements explicit. In a later examination of objectivity in research, Myrdal even went so far as to suggest that a 'disinterested' social science has never existed, and is logically impossible (Myrdal 1969: 55). However, there are degrees of 'impartiality' with regard to both means and ends. Academics not directly associated with political think tanks' are likely to be less partisan than those pursuing research 'for its own sake'.

Academics may play more than one role, particularly those who set themselves up as consultants, serve on advisory boards, or become active in advocacy, or political protest. Inevitably, there may be role-conflicts, and even serious 
conflicts of interest, when objectivity may be jeopardised by the need to please a client, such as a government department or a corporation, or whoever is funding the research. A further dilemma occurs when research results are not consistent, leaving those responsible for formulating policy with the need to ignore some findings, or to choose between them, according to their own pre-suppositions. Not all policy advisors are experts in the subject matters they deal with, although they may draw selectively on the research undertaken by others. Political ideologies and 'party loyalty' may then over-ride other considerations.

Much of the so-called 'policy research' on Canadian immigration questions, carried out in the past (whether undertaken by government departments, academics or the private sector), has been simply an information-gathering process, including the study of public opinion. ${ }^{1}$ The information may be related directly, or indirectly, to the policy decision-making process, or the administration of publicly supported immigration, health, welfare and other social programmes. Very little of the work undertaken in the so-called strategic, applied or policy-oriented fields contributes to the advancement of science. New theoretical advances, methodological breakthroughs, or fundamental contributions to our understanding of human behaviour, are rarely achieved as a consequence of such studies. This is not to underestimate their importance, but it must be understood they can never be a substitute for more basic or 'pure' scientific research, whether in economics, demography, sociology, or any other field.

Immigration is one field where planning and programming has been associated with the Canadian government's own 'in-house' research. This is generally designed to study the effects of immigration on the economy, and the adaptation of immigrants in their first few years in Canada. At the same time there has been extensive academic research on various aspects of the immigration process, together with a growing influence of independent 'think-tanks' and policy institutes. Therefore, it constitutes an interesting case study to consider the contribution that such research has made to the policy and planning process.

\section{Policy issues in immigration}

Among the major policy questions facing Canada in the later 1980s and early 1990s were those generated by global forces. The demise of the Soviet Union, which had maintained strict control of emigration, together with political unrest in Asia, Latin America, Africa and, in due course, Eastern and Central Europe, were contributory factors to a substantial outflow of refugees as well as economic migrants. Border control became a major preoccupation of all advanced industrial countries. New legislation was passed in Canada, and similar laws and regulations in other countries, that empower immigration officers to interdict, and refuse admission to undocumented arrivals, require the departure or the deportation of those who overstayed visas, and failed to meet immigration requirements, or satisfy asylum eligibility criteria. This led to the setting up of an 'Informal Consultations Group', of senior civil servants and politicians from major receiving countries, whose purpose was to 'harmonise' immigration policies (Widgren 1991). There was much debate concerning the need for temporary asylum, on the one hand, and the longer term resettlement of refugees on the other (Adelman and Lanphier 1990). The idea of 'humane deterrence' dominated the policy agenda. There was a growing concern with 
the need for 'early warning' of any future mass movements of population (Richmond 1994: 221; Schmeidl 1997).

Other policy issues in this period revolved around the question of immigration levels, the appropriate balance between the categories of 'independent immigrant' (including business and investor classes), 'family reunion' and 'humanitarian' immigration. Backlogs of applicants in the 'family class', and delays in processing visas in some posts abroad, caused concern. In this connection there was much discussion of the economic costs and benefits of immigration generally, and particular categories of arrivals (Akbari 1989; Akbar and DeVoretz 1993; Coulson and DeVoretz 1993). The use of temporary employment visas, for certain categories of worker, was generally treated as separate from the 'landed' or 'permanent' immigration movement (Boyd et al. 1986; Michalowski 1993).

Further policy questions concerned government assistance toward settlement in early years, in which provincial and municipal governments, as well as voluntary agencies, also had concerns. Levels of support for official language training classes, citizenship education, health and welfare services, and skill retraining were all under review, and were subject to the fiscal restraints that characterised the period. Many of the immigration policy questions merged with those of other government departments. They included multiculturalism, health and welfare, status of women, and justice. Some opponents of immigration focused on security issues, and the dangers of admitting war criminals, terrorists, or those involved in organised crime. Others were more concerned with the economic consequences of immigration, at times of high unemployment. A few raised environmental issues in relation to population growth rates.

\section{Research on Canadian immigration}

A previous article (Richmond 1987) reviewed the demographic and sociological research on Canadian immigration from 1950 to 1979, and concluded:

\footnotetext{
the direct impact of this research on policy and practice has been limited. Although the results of academic research may have filtered into the decision-making process in certain accidental, remote and indirect ways, its influence was muted by the more strident voices of those with special interests. The 'in-house' researchers that were part of the bureaucracy itself hardly fared any better. Their findings (like those of the academic social scientists) generally had, at best, a peripheral influence on government policies and programs. (Richmond 1987: 614)
}

The present article is intended to update the conclusions of the earlier study, by reviewing more recent research, particularly that published 1980-1998. A complete inventory of immigration-related research conducted in this period is not possible here. ${ }^{2}$ However, some of the more important contributions will be considered.

The decade of the 1980s saw a wide range of studies from government and non-governmental sources, although delays in analysis and publication made questionable their relevance for practical policy-making. For example, the longitudinal surveys conducted by the Immigration Department in the period 19691976 obtained information from a sample of immigrant respondents, who had been in the country six months, and annually up to three years in Canada. These data remained virtually unanalysed by the Department until they were resur- 
rected in $1981 .^{3}$ At that time a contract for their analysis was awarded to researchers at York University (Ornstein 1982; Ornstein and Sharma 1983). The studies related selection procedures, and the 'points system', to the outcomes in terms of employment. Among other conclusions, it was found that the occupational demand score was ineffective as a predictor of subsequent employment. After controlling for age, sex and education, there were substantial differences in occupational status and income between immigrants from the USA, the UK and Western Europe, and those from other countries. A review of 25 empirical studies of the economic adaptation of immigrants undertaken between 1969 and 1981 concluded, among other things, that 'visible minorities' experienced additional problems due to prejudice and discrimination (Richmond 1982). These findings were confirmed in subsequent economic analyses (Richmond 1989). However, some research attributed the lower levels of achievement of later cohorts to changes in admission criteria, and to self-selection, rather than to post-migration discrimination (DeVoretz 1995; Duleep and Regets 1992).

The detailed analyses of 1971 census data on Canadian immigration were not published until nearly a decade after the census (Richmond and Kalbach 1980). These studies were undertaken in close co-operation with Australian researchers. The Canadian and Australian censuses had included a question on 'birthplace of parents'. This enabled a three-generational analysis to be made. Despite some formidable technical and methodological problems in ensuring comparability in the definition of variables, some important similarities and differences in the experience of immigrants and their descendants in the two countries were found. The results were reported in three monographs published in 1984-1985. ${ }^{4}$ These dealt with demographic, educational, economic and urban aspects of the immigrant experience in the two countries (Burnley and Kalbach 1985; Rao et al. 1984; Richmond and Zubrzycki 1984).

A survey conducted in metropolitan Toronto in 1982 further analysed the generational dimension in immigrant absorption, comparing educational achievement and occupational status (Kalbach et al. 1984; Richmond 1986). These studies highlighted the long-term impact of immigration on the receiving countries. Surveys were carried out, some in co-operation with voluntary organisations concerned with immigrant settlement (Sharma 1980; 1981). These studies demonstrated the need for settlement assistance that went beyond the three-year limit of government funding for voluntary organisations assisting immigrants. The 1981 census gave rise to a number of shorter monographs dealing with immigration in terms of demographic and economic variables (Beaujot et al. 1988), including a special study of Caribbean migration (Richmond 1989).

Other surveys conducted in 1970-1980 were academically initiated and not published in book form until much later, although some articles and monographs appeared earlier. They dealt with issues related to economic achievement, ethnic identity and equality. (Boyd et al. 1985; Breton et al. 1990). Policy-oriented studies based on 1981 and 1986 census data were conducted by the Institute for Research on Public Policy in Ottawa (Seward 1990; Seward and Tremblay 1989). The latter focused on the structural changes taking place in the Canadian economy, and the implications for immigrants in the labour force, including the difficulties facing women with little knowledge of either of the official languages. Further studies of gender differences highlighted the adjustment problems facing immigrant women (Boyd 1987, 1990). Indirectly, the latter 
studies did eventually lead to some modification of government regulations regarding accessibility to language and training programmes for women, but only after the issue had been taken up by women's groups and political pressure applied.

A policy forum on immigration and Canada's future (Beach and Green 1989), included some discussion of Quebec's views on immigration questions, which differed from other provinces in being preoccupied with the cultural and linguistic consequences of immigration. In 1978 Quebec negotiated an agreement with the federal government, extended in scope in 1990, which gave that province special powers to recruit immigrants and to provide settlement services. This occurred in a context of low rates of natural increase and fears for the future of the French language in Quebec.

Demographers debated the relative importance of pro-natalist policies over encouraging francophone immigration (Henripin and Pelletier 1986). Research on the ethnic demography of other immigrant groups, and their descendants in the rest of Canada, were reported in Halli et al. (1990). From a political science perspective, Freda Hawkins (1989) published a comparison of Canadian and Australian immigration policies. She noted the dominant influence, in both countries, of the public service as policy decision-makers, but considered that Australia benefited more than Canada from the expert advice of its own advisory bodies. She wrote:

The Canadian advisory councils in this field have not been trusted by the government, have not operated at a sufficiently senior level, and, so far, have not been allowed to play any significant role' (Hawkins 1989: 254).

Dirks (1995: 40) examined the process of public consultation which preceded the annual determination of intended immigration levels, and also found that the Advisory Council's influence was limited. The advisory bodies had no research budget and relied upon reviews of secondary sources. The Canada Employment and Immigration Advisory Council conducted a number of studies and submitted reports with recommendations to the Minister (CEIAC 1991 but few of these were implemented. The Council was disbanded in $1992 .^{5}$

In the mid-1980s Health and Welfare Canada initiated the Demographic Review. It enlisted the Royal Society of Canada, and other distinguished academic researchers, to examine long-term population trends in Canada, including the implications of declining fertility and the ageing of the population. Immigration was also a topic for research under the auspices of this programme. Historical, demographic, geographic and economic questions were considered, but the terms of reference and budgets permitted only a review and summary of existing research findings. No new research was undertaken. The final report of the Review argued that declining fertility rates would have a long-term effect on the population, leading to an eventual decline, unless immigration made up the difference. (Beatty 1989). As in most other demographic studies, no attention was paid to the possible effects of emigration. An exception was a study prepared for the Department of Employment and Immigration (Beaujot and Rappak 1989). There was rivalry between Health and Welfare Canada and Employment and Immigration Canada concerning demographic research and policy, and an apparent indifference to these issues among Parliamentarians and the public (Dirks 1995: 120-1). However, by 1998-1999 there was growing 
concern at an apparent 'brain drain' to the USA, facilitated by special arrangements under NAFTA (the free trade agreement).

Health and Welfare Canada, and the Ministry of State for Multiculturalism, jointly instituted a Task Force on 'Mental Health Issues Affecting Immigrants and Refugees' that reported in 1988. As well as stressing the need for more empirical research on the effectiveness of health and welfare services for immigrants, the Task Force made a total of 27 specific recommendations, including the need for more effective pre-migration orientation and improved services after migration (Beiser 1988). Unfortunately, due mainly to fiscal constraints, few of these recommendations were implemented.

The Economic Council of Canada undertook a major study of the economic and social impact of immigration (Swan 1991). It recommended avoiding sudden increases in immigration levels, but proposed a gradual rise in immigration from the average of the preceding 25 years (i.e. 168,000) to one per cent of the population by the year 2015. However, the government had already announced an increase in targeted levels to 250,000 for the next five years! The Council was concerned that such high levels might 'run the risk of provoking social problems' (Swan 1991: 35). A number of other recommendations were made by the Council. These went beyond purely economic considerations to include the socio-cultural impact, and the need to combat racism. These recommendations were largely ignored, or received only a token response, and, shortly afterwards, the Economic Council of Canada was dismantled, ostensibly as a consequence of budget-cutting measures.

Concurrently with the burgeoning research output from academic, government and other sources, some fundamental changes were taking place in Canadian immigration policy and legislation. Business immigration was promoted without prior research, or subsequent monitoring, until serious difficulties with the programme revealed themselves (Borowski and Nash 1994). A subsequent report by the Auditor General confirmed serious irregularities.

Refugee issues came to the fore nationally and internationally. Little research had been done on this question, after the initial interest immediately following World War II. A Centre for Refugee Studies was established at York University, with an initial five-year grant from CIDA. The research included studies of countries from which refugees were coming, as well as the experiences of refugees in camps, and after settlement in Canada, following selection abroad, or successful asylum application. (Adelman 1991). Further comparative studies of Canada and Australia were undertaken (Adelman et al. 1994). Canada and the USA were also compared in respect of their immigration policies, and the economic adaptation of immigrants (Borjas 1988; Chiswick 1992), and also with regard to their increasingly multicultural character (Reitz and Breton 1994).

What is notable about these studies is that they mostly occurred after Canada debated new legislation in the late 1980s. Various other amendments to immigration legislation occurred in the 1990s. Although some academics were critical of many of the new provisions, their input into the new policies was mainly through submissions at parliamentary committee hearings, and consultations with senior bureaucrats who listened to, but did not necessarily accept, their expert advice. As mandated by the 1978 immigration legislation, Citizenship and Immigration Canada conducts annual public consultations on immigration levels and related matters with provincial governments, and other 'stakeholders' in the immigration process. In 1994, these consultations were quite 
extensive, and included a number of 'working groups' which addressed various questions concerning immigration policies, culminating in the publication of a report titled 'Into the $21^{\text {st }}$ Century: A Strategy for Immigration and Citizenship' (CIC 1994).

Economists appeared to be more influential in the corridors of power than demographers or sociologists. Econometric studies that appeared to show that independent immigrants and entrepreneurs made a greater net contribution than the family class, or refugees, did coincide with some shift in the composition of government's annual 'targets' for immigration (DeVoretz 1995). After 1994 there was less emphasis on family reunion and more efforts were made to encourage skilled workers and investors.

Suffice to say that whether the research was specifically intended to have policy relevance, or designed purely as an academic thesis, the findings had to compete with newspaper editorials, public opinion polls, interest groups, provincial preferences, bureaucratic concerns, global pressures and budgetary considerations, all of which probably played a greater part in determining policy outcomes (Dirks 1995: 30). In Canada, as in Australia, officials expressed concern that they may have lost the ability to manage and control immigration effectively, due to pressure from sponsors, advocacy groups and 'self-selected' migrants (Burstein et al. 1994).

\section{New research initiatives}

In 1995, the Department of Citizenship and Immigration announced a new research initiative, originally called the 'Cities' and subsequently the 'Metropolis Project'. It called for closer collaboration between government departments, universities and non-governmental organisations in the conduct of policy-related research on immigration. The original announcement even anticipated the possibility of international comparisons and co-operation in immigration research. ${ }^{6}$ A year later, after competitive bids from universities were received, four 'Centres of Excellence' were established in Montreal, Toronto, Edmonton and Vancouver, each committed to inter-disciplinary and inter-institutional research initiatives. The themes identified by the immigration department as having priority were extensive. They included the effects of immigration on urban economies; the impact on government and non-governmental services; the social, cultural and political effects of immigration; the relationship between immigration, enclaves and the urban underclass; the social integration of young immigrants; and the impact of immigration on intergroup attitudes and social harmony. The new Centres are not expected to address all these questions but the agenda is an ambitious one.?

Concurrently with the establishment of the university-based research centres, the Department of Citizenship and Immigration, working with Statistics Canada, created a linked database, using immigrant visa data and tax files, in order to monitor the economic achievements of immigrants. At the same time, Statistics Canada planned a longitudinal survey of immigrants, commencing in 19971998, which will monitor immigrants at intervals, for a period of four years.

In 1997 the government set up an 'Immigration Legislative Review', with its own Advisory Group, with a mandate to consult with experts, and other interested parties, and to make recommendations for updating legislation and 
policies. The authors of the report (Trempe et al. 1998) consulted widely with governmental and non-governmental agencies, and with academics who had undertaken research on immigration questions. The report contained 172 recommendations for the revision of Canadian law, regulations and programmes concerning immigrants and refugees. One of the most controversial proposals concerned the higher level of official language ability, which the Advisory Group considered should be a requirement for 'economic' or 'self supporting immigrants', before admission. This proposal received much publicity and, following public consultations, the Minister indicated that it was not the government's intention to proceed with the implementation of this recommendation. In the department's Report on Plans and Priorities 1998-99 (CIC 1998) it was stated that the department would 'review the results of the consultative process in conjunction with extensive analysis of the report'. Meanwhile, the department would carry out its performance commitments, as outlined in the 1997 report to parliament.

So far, the Review has not resulted in any new immigration regulations, although proposals to raise required educational qualifications for admission have been aired. If implemented they would make it difficult for skilled tradespeople to be admitted as preference would be given to those with university degrees (Laghi 1999). In November 1998 the Minister of Immigration announced plans to revise requirements for naturalisation. Currently, Canadian citizenship can be obtained after three years residence, but some Citizenship Court judges had interpreted this requirement liberally, regarding the ownership of property and/or the payment of taxes in Canada as sufficient. Proposals to tighten citizenship rules, and to revise the form of the oath of allegiance, evoked immediate protest from immigration lawyers assisting business immigrants and investors whose 'globe-trotting' made fulfilment of the residence requirements difficult. A new bill tightening residence requirements for citizenship was introduced in 1999 . The bill also proposed amendments to the wording of the citizenship oath taken by those taking out citizenship. ${ }^{8}$ The Bill died on the order paper. A new version was introduced in November 1999.

Although social scientists are expected to make their research relevant to national concerns, and of use to those responsible for formulating public policy and administering social programmes, actual real dollar expenditure on academic social research has declined in the last decade. An increasing proportion of federal and provincial research budgets has been spent on studies contracted out to private and commercial agencies, particularly public opinion surveys. The Social Sciences and Humanities Research Council of Canada allocates a proportion of its funds to so-called 'strategic' areas. It is now co-operating financially with the Canadian government in the funding of projects initiated under the auspices of the new Centres of Excellence.

Inevitably, several questions arise. First, will there be opportunities, in the future, for academic researchers to pursue knowledge and research 'for its own sake' i.e. in pursuit of theoretical and scientific questions not of immediate practical value? Second, will the researches commissioned under the auspices of the 'Metropolis Project' have any obvious and direct impact on immigration policies and administrative decision-making? Third, will there be a role for the 'social critic', who questions the fundamental premises of contemporary global capitalism, including its political, demographic, economic and environmental consequences? 


\section{Conclusion}

Social scientists continue to work closely with government officials in the conduct of research having a direct relevance to immigration questions. In addition, various government departments fund economists, sociologists and other researchers whose work is believed to have practical implications for immigration policy, and for the subsequent economic, socio-cultural and political integration of immigrants. However, in the period 1980-1998, as in previous decades, the direct impact of research on immigration policies was limited. Academic, 'think-tank', or commissioned research may have filtered through the media, or other channels, but the findings had to compete with the influence of lobbyists, political parties, and senior bureaucrats, and had only a peripheral influence. The 'in-house' researchers that were part of the bureaucracy itself had a similar experience. Their findings (like those of the academic social scientists) were often ignored, or rejected as politically impractical, or fiscally imprudent.

A clear example is the problem of non-recognition of the foreign qualifications of skilled and professional immigrants, and the difficulties thus created for their integration. This was first identified by federal government researchers in the 1950s, and by almost every report by academic and other researchers since, but little action has been taken. ${ }^{9}$ The issue comes under Provincial rather than Federal jurisdiction, and also involves the interests of professional associations and labour unions who have been slow to respond. The latter place restrictions on inter-provincial recognition of certification as well as on the recognition of foreign credentials.

Other recommendations that have been made in more than one report, and not fully adopted, include the need for pre-migration orientation, more effective official language-training before and after arrival, greater efforts to combat racism, public education concerning the benefits of immigration, improved community and mental health services for immigrants and refugees, and crosscultural training for education, health and welfare practitioners. A combination of fiscal constraints, together with shifting responsibilities between federal, provincial or municipal levels of government, and the private sector, have led to frustration. A conservative and neo-liberal climate of government cutbacks and devolution has given rise to what may be called 'post-multiculturalism'. In this context immigrants and refugees, and the non-governmental organisations that endeavour to assist their settlement in Canada, are obliged to fend for themselves to a much greater degree (Lanphier 1997).

These conclusions, based on a review of Canadian experience with regard to immigration policy, concur with those of Carol Weiss who has undertaken extensive studies of research and policy-formation in the USA and elsewhere (Weiss and Bucavakis 1980; Weiss 1982; 1990). In Wagner et al. (1991: 307-32) Weiss wrote, 'From the outset let us recognise that policy research, or any other kind of research, is not going to determine the major direction of policy ...'. Ideologies and interests determine the course of events but:

Policy research is a supporting player in the drama of policy making. The empirical question is under what conditions research gets on stage at all, and when it does, what consequences it has for the unfolding of the action. (Wagner et al. (1991: 308)

Why has research made so little impact on the policy-formation process and the implementation of programmes? The answer lies in the nature of the process itself, as applied both to the generation of research, and the dissemination of 


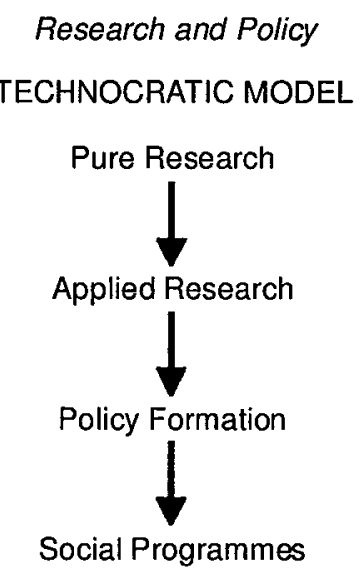

Figure 1.

findings. Wittrock (1991: 341) identified several ways in which social scientific findings may enter the decision-making process, including the technocratic, the bureaucratic, and the enlightenment models. The technocratic model assumes a direct link between pure, or applied, research and the policy-formation process (see Figure 1.). It is doubtful whether such a simplistic link is realistic, even in the case of the physical and biological sciences, much less in the social sciences.

The bureaucratic model (Figure 2) recognises a less direct, more complex and selective, process whereby research may influence decision-making. It is evidently implicit in a recent 'policy-research initiative' undertaken by the Canadian Privy Council Office. The latter attempts to co-ordinate in-house, contracted-out, and government funded academic research throughout the federal bureaucracy. It does so through conferences, networking and funding decisions in relation to research, ranging from science policy to economic strategies to health and population issues. It is essentially a 'top-down' system of control.

The 'enlightenment' model (Figure 3) assumes no direct link between research and policy-making, but recognises that the findings of research may be disseminated through academic conferences, journals, classroom teaching and occasional journalistic highlighting, before exerting an influence on policies. The influence is long-term. Whereas, the time frame for decision-making by govern-

Research and Policy

BUREAUCRATIC MODEL

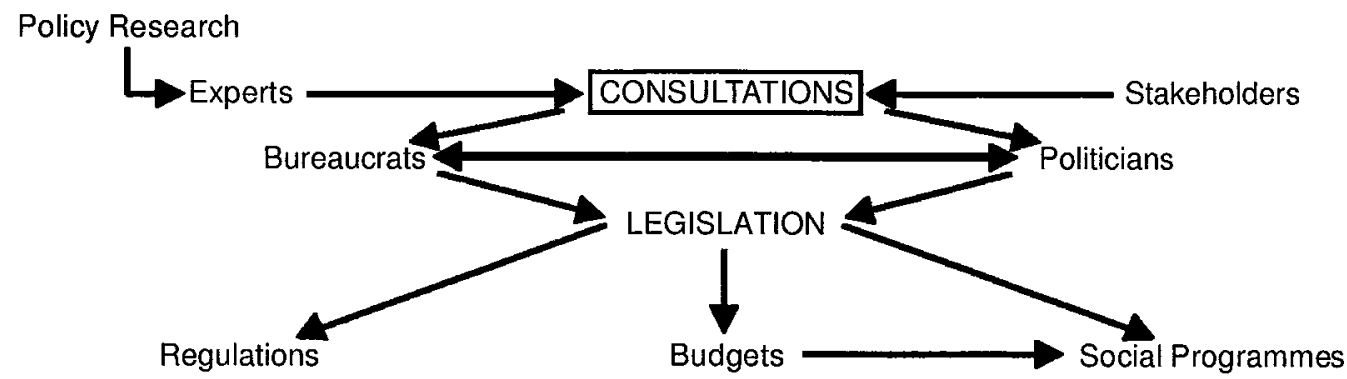

Figure 2. 


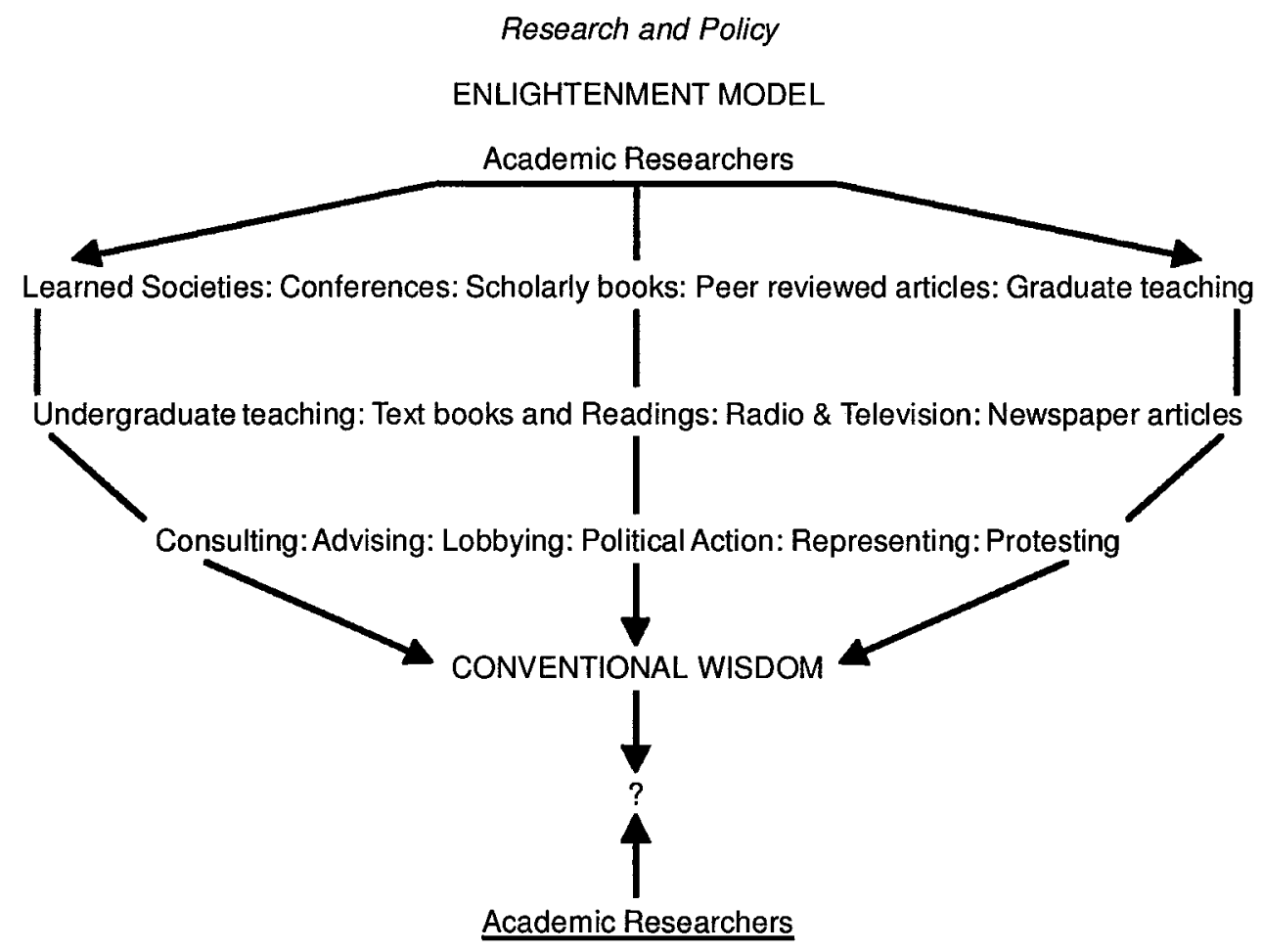

Figure 3.

ment policy-makers is generally related to electoral strategies, academic research and the dissemination of findings generally involve a much longer span, sometimes as much as a generation. Eventually social science becomes incorporated into 'conventional wisdom'. It is generally understood that academics have a responsibility to question such 'common-sense' ideas, as well as their own earlier findings, in the light of changing social conditions. Research too closely tied to current policy priorities may not facilitate such a critical role.

To these models may be added another, namely the 'systems' model (Figure 4). The latter recognises that research emanates from a variety of sources, and must compete with the special pleadings of interest groups, political parties, and the media, for influence on the officials and politicians who determine the policy outcomes. Lindquist (1990: 21-51) pointed to the rise of a 'third community' i.e. policy institutes, government councils and commissions, consultants and interest groups, all of whom contribute information, and endeavour to influence policy decisions. In considering particular policies, it is important to recognise that any programme necessarily competes with others for recognition, for priority, and for the allocation of resources. Budgets are seen as enabling by bureaucrats and politicians but, at times of government cutbacks, are more likely to be perceived as constraining effective action by practitioners and users of social programmes.

The adoption of a particular policy, in a given field, furthermore has repercussions on others. All social systems involve interactions and feedback processes, in which there may be entirely unanticipated consequences. Global conditions (including local, national and the changing world system) have a significant impact on economic and social policies. This is true in most fields, but is particularly important in the sphere of immigration, where global demographic, 
Academics; Think Tanks; Journalists; Corporations; Labour Unions; Non-Governmental Orgs.

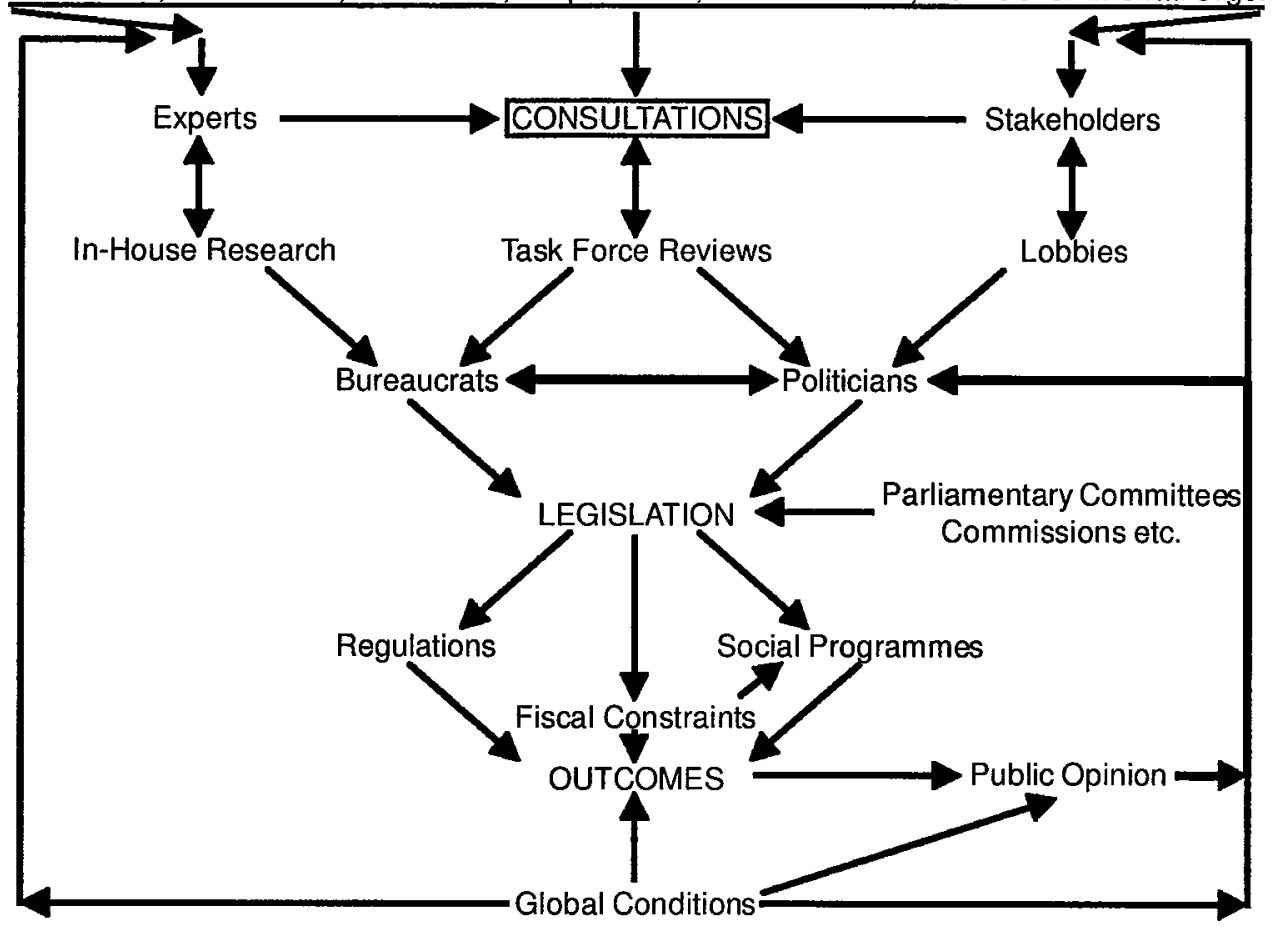

Figure 4 .

economic and political factors play an important part in determining population movements, and government reactions to them.

In practice, there is a lack of synchronisation between the research undertaken and the decision-making process. Research that is to be of any significant value to policy-makers is generally expensive and time-consuming. There is often a long delay between the initial investigation, or data collection, and the eventual publication of results. ${ }^{10}$ By the time a social problem is identified, and academic researchers have begun to investigate it, the need to make decisions is often urgent. More often than not, the relevant facts and figures upon which a rational decision might be reached are not available. Decisions must be made in a hurry and in anticipation of research findings, which may or may not lend support to the choices made. The findings of research must compete with the often unfounded claims of more vocal pressure groups.

As Simmons and Keohane pointed out:

Immigration and refugee policies have been hotly contested matters in Canada and are likely to remain so. A wide spectrum of actors are involved, and they function within a rather volatile field of public views and sentiments .... it is not surprising that policy can change quickly, contain major internal inconsistencies, and appear to vary with the whims of the current government ... . (1992: 44)

Studies of other policy communities and networks (such as the poverty lobby, fisheries, banking etc.) have demonstrated that relatively autonomous state bureaucracies, faced with pluralist, or loosely-organised interest groups can 
initiate changes favoured by the government more easily than when facing a concerted, or closed, pressure network (Coleman and Skogstad 1990: 325-6). Where immigration is concerned, there is little consensus on the issues involved. On the contrary, lobbyists have competing and contradictory interests. They range from right-wing opponents to any immigration (except from traditional sources' such as Britain and the USA), to those who argue for family reunion, humanitarian and refugee admissions, skilled workers, and/or capitalist investors, respectively. Similarly, there are debates among those who consider governments should fund more language classes and settlement services, and those who wish to see greater responsibility delegated to private agencies. The 'immigration industry' includes lawyers who specialise in asylum cases, or process applications by entrepreneurs and investors, together with interpreters, teachers of English or French as a second language, and ethnic community social workers (not to mention immigration researchers!)

In these circumstances, research comes to be seen, by bureaucrats and politicians, as a means for the retroactive rationalisation and justification of past decisions. Research findings (whether the studies are carried out 'in-house', in universities or policy institutes) may be used selectively to provide support for policies that have been determined in an entirely different context. Senior bureaucrats, and political assistants to the minister in question, control the flow of information. Positive feedback, in the form of research findings that are supportive of existing policies, flow more readily than negative feedback that is critical.

There are a number of lessons to be learned from this review of social research and its contribution to immigration policy in Canada. If academic researchers are to make any impact upon the policy-formation process they must be alert to the identification of problems and issues, long before these become fully articulated and defined at the political level. Furthermore, there must be a more expeditious translation of research into published work, in a form that will influence decision-makers, before special interest groups can take advantage of the vacuum, and obscure the reality with ideological invective. Once issues have surfaced and are being debated in the press, and on the hustings, academics must be prepared to make their findings known in as simple and intelligible a form as possible, in order to combat the uninformed and, sometimes, malicious claims of those whose partisan positions stem from ignorance or prejudice.

Finally, the researchers must be constantly alert to the dangers of censorship, or the more subtle forms of editing and selection that go into the presentation of results to those who make decisions. In this respect the 'executive summary', so beloved of senior bureaucrats and politicians, can be misleading. Stripped of all the qualifications spelled out in the main text, such documents are the means by which positive reinforcing feedback supersedes the negative. Critical information emanating from the research is thus diluted. 'Spin doctoring', in the form of selective press releases of research that appears to support the government's current programme, falls into a similar category. Research findings become a tool for the management of opinion and the generation of consensus.

This review of the impact of research on immigration policy in Canada shows that if the 'mills of research' grind exceedingly slow, they also ground too small and too quietly in the past to have had any major influence on the political process. Social scientists are faced with a dilemma. They must either withdraw into their 'ivory towers', and forego the satisfaction of changing the world, or be 
prepared to become politically active. This would mean expressing their views and pressing their conclusions, in competition with the many other lobbyists in the 'corridors of power'. Given the importance governments today place on opinion polls, there is clearly a need for a more enlightened public, Myrdal's admonition, 30 years ago, is still pertinent today:

... too many social scientists today are increasingly addressing only each other. This trend to false scientism, this forgoing of the responsibility for the formation of public opinion, is apt to decrease the importance of our work for making people more rational (Myrdal 1969: 42).

It remains to be seen if the researchers engaged in the 'Metropolis Project' succeed in being more influential than their predecessors. Hopefully, the need for 'pure' research will not be altogether neglected. An ideal institutional framework might be one in which fundamental research is undertaken, but serendipitous discoveries of practical value occur. It will be incumbent on the researchers to ensure that these discoveries are expeditiously communicated to policy-makers and the public.

\section{Acknowledgements}

This is a revised version of a 'Working Paper' presented at a panel discussion on research and policy at CERIS (Joint Centre of Excellence for Research on Immigration and Settlement) Toronto, 4, November 1998) The author wishes to thank colleagues, and referees, who made constructive suggestions for the revision of earlier drafts of the paper on which this article is based. The author alone is responsible for the views expressed.

\section{Notes}

1 In recent years there has been an exponential growth in the use of public opinion polling, including focus groups and other techniques, which not only measure opinion but, with the aid of public relations specialists ('spin doctors') and the media, enable government officials and politicians to 'manufacture consent' (Herman and Chomsky 1988). Questions concerning immigration policy have been included in a number of government surveys.

2 An 'Annotated Bibliography of Canadian Immigration Research' compiled, and edited by Jane Barr, Myriam Mansour, and Alan Nash, is available on computer disk from Concordia University. Contrary to Globerman (1992: 6), who suggested that there was a 'relative scarcity' of research on the impacts of immigration, the lengthy inventory suggests that the research actually undertaken has not entered significantly into the policy debates.

3 A preliminary analysis of the first cohort arriving in 1969 was published as part of the Green Paper on Immigration, Canadian Immigration and Population Study in 1974 (Manpower and Immigration 1974).

4 There were plans for a book to be published simultaneously by University of Toronto Press and the Australian National University Press. When the ANU Press found itself in financial difficulty the proposal was withdrawn by the Canadian publishers. The results were subsequently published by York University in a series of monographs (see references below).

5 From time to time, academic social scientists were consulted by senior officials in the Immigration Department on questions relating to immigration levels, the demographic and economic impacts of immigration and integration questions. Their influence on eventual policy-formulation was diluted by competing influences, including 'business, labour, ethnic communities, humanitarian groups, provinces etc.' (Simmons and Keohane 1992: 444).

6 The possibility of such co-operation with Australia was rendered unlikely when the newly elected government in that country abolished the Bureau of Immigration Research, which had been involved in a number of studies in Australia, and in co-operation with Canadian academics.

7 However, notably absent from the list were studies of the operation of the Immigration 
Department itself, the refugee determination process, border control and enforcement, return migration, or the global factors influencing population movements.

8 The old oath required swearing allegiance to Her Majesty the Queen. The proposed revision inserts' Canada' before 'the Queen'!

9 See Richmond 1967 p. 59 fn.22; Cumming et al. 1989, and Toronto Globe and Mail, 'Skilled immigrants meet job barriers', 19 November 1996. A conference on the subject was held in Toronto in 1996.

10 For example, an article published in 1997 noted that European immigrants do better economically than those from Third World countries. It was based on data for the period 1981-1984 (see DeSilva 1997).

\section{References}

Adelman, H. (Ed.) (1991) Refugee Policy: Canada and the United States, Toronto/New York: York Lanes Press and Center for Migration Studies

Adelman, H., A. Borowski et al. (Eds) (1994) Immigration and Refugee Policy: Australia and Canada Compared, 2 vols, Toronto: University of Toronto Press

Adelman, H. and C.M. Lanphier (Eds) (1990) Refuge or Asylum: A Choice for Canada, Toronto: York Lanes Press

Akbari, A.H. (1989) 'The benefits of immigration for Canada: evidence on tax and public services', Canadian Public Policy, Vol. XV No. 4, 924-35

Akbar, S. and D.J. DeVoretz (1993) 'Canada's demand for Third World highly trained immigrants, 1976-86', World Development, Vol. 21 No. 1, 177-87

Beach, C. and A.G. Green (Eds) (1989) Policy Forum on the Role of Immigration in Canada's Future, Kingston: Queen's University Press

Beatty, P. (1989) Charting Canada's Future: A Report of the Demographic Review, Ottawa: Health \& Welfare Canada

Beaujot, R., K.G. Basavarjappa and R.B.P. Verma (1988) Income of Immigrants in Canada, 1980, Ottawa: Statistics Canada

Beaujot, R. and J.P. Rappak (1989) 'The link between immigration and emigration in Canada, 1945-1986', Canadian Studies in Population, Vol. 16. No. 2, 201-16

Beiser, M. (1988) After the Door has been Opened: Mental Health Issues Affecting Immigrants and Refugees in Canada, Ottawa: Health \& Welfare Canada

Borjas, G.J. (1988) International Differences in the Labor Market Performance of Immigrants, Kalamazoo, Michigan: Upjohn Institute

Borowski, A. and A. Nash (1994) 'Business immigration', in H. Adelman, A. Borowski et al. (Eds), Immigration and Refugee Policy: Australia and Canada Compared, Vol. 1, 227-52

Boyd, M. (1987) Migrant Women in Canada: Profiles and Policies, Monitoring Panel on Migrant Women, OECD, Ottawa: Employment and Immigration Canada

Boyd, M. (1990) 'Immigrant women: language, socioeconomic inequalities and policy issues' in S.S. Halli, L. Driedger et al., Ethnic Demography: Canadian Immigrant, Racial and Cultural Variations, 275-96

Boyd, M., J. Goyder et al. (1985) Ascription and Achievement: Studies in Mobility and Status Achievement in Canada, Ottawa: Carleton University Press

Boyd, M., C. Taylor and P. Delaney (1986) 'Temporary workers in Canada: a multi-faceted program', International Migration Review, Vol. 20 No. 4, 929-950

Breton, R., W.W. Isajiw et al. (1990) Ethnic Identity and Equality: Varieties of Experience in Canada, Toronto: University of Toronto Press

Brooks, S. and A.-G. Gagnon (1988) Social Scientists and Politics in Canada: Between Clerisy and Vanguard, Kingston and Montreal: McGill Queen's Press

Brooks, S. and A.-G. Gagno (Eds) (1990) Social Scientists, Policy and the State, New York: Praeger

Burnley, I.H. and W.E. Kalbach (1985) Immigrants in Canada and Australia, Vol. 3. Urban and Ecological Aspects, Toronto: Institute for Behavioural Research, York University

Burstein, M., L. Hardcastle and A. Parkin (1994) 'Immigration management control and its policy implications', in H. AdeIman, A. Borowski et al. (Eds), Immigration and Refugee Policy: Australia and Canada Compared, 187-226

Canada: Employment and Immigration Advisory Council (1991) Immigrants in the 1990s, Ottawa: CEIAC

Canada: Citizenship and Immigration Canada (1994) Into the $21^{\text {st }}$ Century: A Strategy for Immigration and Citizenship, Ottawa: Ministry of Supply and Services 
Canada: Citizenship and Immigration Canada (1998) Report on Plans and Priorities 1998-99, Ottawa: CIC

Chiswick, B.R. (Ed.) (1992) Immigration, Language and Ethnicity: Canada and the United States, Washington D.C.: The AEI Press

Coleman, W.D. and G. Skogstad (Eds) (1990) Policy Communities and Public Policy in Canada, Mississauga, Ontario: Copp Clark Pitman

Coulson, R.G. and D.J. DeVoretz (1993) 'Human capital content of canadian immigration', 1967-87', Canadian Public Policy, Vol. XIX No. 4, 357-66

Cumming, P., E. Lee and D.G. Oreopoulos (1989) Access! Task Force on Access to Professions and Trades in Ontario, Toronto: Ontario Ministry of Citizenship

DeSilva, A. (1997) 'Earnings of immigrant classes in the early 1980s: a re- examination', Canadian Public Policy Vol. XXIII No. 2

DeVoretz, D.J. (Ed.) (1995) Diminishing Returns: The Economics of Canada's Recent Immigration Policy, Toronto: C.D. Howe Institute

Dirks, G.E. (1995) Controversy and Complexity: Canadian Immigration Policy During the 1980s, Montreal: McGill Queen's Press

Dobuzinskis, L. (1996) 'Trends and fashions and the marketplace of ideas' in L. Dobuzinskis, M. Howlett and D. Laycock (Eds), Policy Studies in Canada: The State of the Art, Toronto: University of Toronto Press

DuLeep, H.O. and M.C. Regets (1992) 'Some evidence of the effects of admissions criteria on immigrant assimilation' in B.R. Chiswick (Ed.), Immigration, Language and Ethnicity: Canada and the United States, Washington D.C. The AEI Press

Globerman, S. (1992) The Immigration Dilemma, Vancouver B.C.: The Fraser Institute

Halli, S.S., F. Trovato et al. (Eds) (1990) Ethnic Demography: Canadian Immigrant, Racial and Cultural Variations, Ottawa: Carleton University Press

Hawkins, F. (1989) Critical Years in Immigration: Canada and Australia Compared Kingston: McGillQueens

Henripin, J. and L. Pelletier (1986) ‘Un quart d'allogènes au Quebec dans 100 ans?', Cahiers Québécois de démographie Vol. 15, 227-51

Herman E.S. and N. Chomsky (1988) Manufacturing Consent: The Political Economy of the Mass Media, New York: Pantheon Books

Kalbach, W.E., C.M. Lanphier, D. Rhyne and A.H. Richmond (1984) Ethnogenerational Factors in Socioeconomic Achievement in Toronto: The Second Generation in the 1970s, Toronto: Institute for Social Research, York University

Laghi, B. (1999) 'Immigrants face tighter rules: federal blueprint would discourage newcomers who don't have university degrees', Globe and Mail, 25 September

Lanphier, M. (1997) 'Devolution in post-multicultural society', Refuge, Vol. 15 No. 6, 1-5

Lindquist, E. A. (1990) 'The third community: policy, inquiry and social scientists', in S. Brooks and A.-G. Gagnon (Eds), Social Scientists, Policy and the State, New York: Praeger

Manpower \& Immigration (1974) Three Years in Canada, Ottawa: Supply \& Services

Michalowski, M. (1993) 'Redefining the concept of immigration to Canada', Canadian Studies in Population Vol. 20 No. 1, 59-84

Myrdal, G. (1958) Value in Social Theory: A Selection of Essays on Methodology (edited by Paul Streeton), London: Routledge and Kegan Paul

Myrdal, G. (1969) Objectivity in Social Research, New York: Pantheon Books

Ornstein, M. (1982) The Work Experience of Immigrants to Canada 1969-1976, Toronto: Institute for Behavioural Research, York University

Ornstein, M. and R.D. Sharma (1983) Adjustment and Economic Experience of Immigrants in Canada: An Analysis of the 1976 Longitudinal Survey of Immigrants, Toronto: York University, Institute for Behavioural Research

Rao, G.L., A.H. Richmond and J. Zubrzycki (1984) Immigrants in Canada and Australia, Vol. 1, Demographic Aspects and Education, Toronto: Institute for Behaviour Research, York University

Reitz, J.G. and R. Breton (1994) The Illusion of Difference: Realities of Ethnicity in Canada and the United States, Toronto: C.D. Howe Institute

Richmond, A.H. (1967) Postwar Immigrants in Canada, Toronto: University of Toronto Press

Richmond, A.H. (1982) Comparative Studies of the Economic Adaptation of Immigrants in Canada: $A$ Literature Review, Toronto: Institute for Behavioural Research, York University

Richmond, A.H. (1986) 'Ethnogenerational variation in educational achievement', Canadian Ethnic Studies Vol. XVIII No. 3, 89

Richmond, A.H. (1987) 'Demographic research and public policy: the case of immigration', in 
Demography, Methodological and Substantive: Essays in Honour of Dr Karol J. Krotki, Edmonton: Department of Sociology, University of Alberta, 597-622

Richmond, A.H. (1989) Caribbean Immigrants in Canada: A DemoEconomic Analysis, Ottawa: Statistics Canada

Richmond, A.H. (1994) Global Apartheid: Refugees, Racism and the New World Order, Toronto: Oxford University Press

Richmond, A.H. and W.E. Kalbach (1980) Factors in the Adjustment of Immigrants and their Descendants, Ottawa: Statistics Canada

Richmond, A.H. and J. Zubrzycki (1984) Immigrants in Canada and Australia, Vol. 2, Toronto: York University, Institute for Behavioural Research

Schmeidl, S. (1997) 'The continuing quest for early warning and early response', Refuge Vol. 16 No. $1,1-3$

Seward, S. (1990) Challenges of Labour Adjustment: The Case of Immigrant Women in the Clothing Industry, Ottawa: Institute for Research on Public Policy

Seward, S. and M. Tremblay (1989) Immigrants in the Canadian Labour Force: Their Role in Structural Change, Ottawa: Institute for Research in Public Policy

Sharma, R.D. (1980) Immigrant Needs in Metropolitan Toronto, Toronto: Institute for Behavioural; Research, York University

Sharma, R.D. (1981) Perceived Difficulties of Foreign-Born Population and Services of Agencies, Toronto: Institute for Behavioural Research, York University

Simmons, A. and K. Keohane (1992) 'Canadian immigration policy: state strategies and the quest for legitimacy', Canadian Review of Sociology and Anthropology Vol. 24 No. 4, 421-52

Swan, N. (1991) New Faces in the Crowd: Economic and Social Impacts of Immigration, Ottawa: Economic Council of Canada

Trempe, R., S. Davis and R. Kunin (1998) Immigration Legislative Review, Ottawa: Minister of Public Works and Government Services, Cat. No. Ci63-21/1998E

Wagner, P., C.H. Weiss et al. (1991) Social Sciences and Modern States: National Experiences and Theoretical Crossroads, Cambridge: Cambridge University Press

Weiss, C.H. (1982) 'Policy research in the context of diffuse decision-making', Policy Studies Review Annual, Vol. 6, 19-36

Weiss, C.H. et al. (1990) Debates on Evaluation, Newport: Sage Publications

Weiss, C.H. and M.J. Bucavakis (1980) Social Science Research and Decision-Making, New York: Columbia University Press

Widgren, J. (1991) 'The management of mass migration in a European context', Statement at Royal Institute of International Affairs, London, 12 March

Wittrock, B. (1991) 'Social knowledge and public policy: eight models of interaction', in P. Wagner et al. (Eds), Social Sciences and Modern States: National Experiences and Theoretical Crossroads, Cambridge: Cambridge University Press

\section{Author details}

Anthony H. Richmond is Emeritus Professor of Sociology, York University, Toronto. He may be contacted at:

Department of Sociology

York University

4700 Keele St.

Toronto

Ontario M3J 1PJ

Canada

E-mail: Anthony Richmond < richmond@YorkU.CA > 